\title{
CONGRATULATIONS TO \\ VALERII PETROVICH PETRUKHIN
}

Doctor of Technical Sciences, Professor, and director of the Scientific-Research Institute of Foundations and Underground Structures

\section{ON YOUR 70th BIRTHDAY}

Valerii Petrovich Petrukhin is an outstanding scientist in the field of soil mechanics, foundation engineering, and underground structures, and one of the founders of the scientific school of foundation construction on saline soils. He and his students were the first in world practice to develop scientific bases for construction on saline soils, which make it possible to exploit vast land areas in the south of the country, which had previously been considered unsuitable for construction.

Results of Mr. Petrukhin's studies form the basis for a large set of Russian regulatory documents (Construction Rules and Regulations, GOST, etc.), which regulate methods of construction on these soils, and have also been incorporated into appropriate sections of regulatory documents of countries in the Commonwealth of National Governments. His developments have been utilized in the design and construction of tens of large-scale projercts intended for industrial and civil purposes, the operating experience of which has confirmed the correctness of the design solutions selected.

Mr. Petrukhin has also made a major contribution to solution of the problem of the safety and reliability of modern urban construction in a dense setting. For more than 10 years, he has been directing studies on scientific-technical accompaniment of the design and construction of large-scale highrise, underground, and transportation structures, as well as on the reconstruction of unique historical entities. Basic regulatory documents for the design and installation of foundations for buildings and structures in Moscow - Moscow City Building Code 2.07-01, Moscow City Building Code 4.19-2005, and Moscow Building Code 50-1.2007 - have been developed under his guidance and with his participation.

Since 2006, he has been director of the N. M. Gersevanov Scientific-Research Institute of Foundations and Underground Structures.

His business and scientific contacts, and also scientists and specialists of the Institute with foreign colleagues and their combined work on designs have contributed greatly to increasing acceptance of the Institute as one of the world's largest modern centers of scientific research and experimental studies on problems involving geomechanics and foundation engineering. In 2008, the Institute received the Euro-standard certificate "For outstanding services in bringing Russia and the European Union together in common construction."

Mr. Petrukhin performs major scientific and social work. He participates in the work of national (RSSMGFE) and international (ISSMGE) societies for soil mechanics and geomechanics, directs the technical committee of the international society for saline soils, participates actively in the work of the committee for construction on weak soils, and collaborates with many leading specialists of foreign geotechnical companies and organizations.

Mr. Petrukhin has authored more than 150 published works, and 30 author inventions. He has prepared a large number of Candidates of Technical Sciences, who are successfully employed in our country, and countries of the Commonwealth of National Governments.

Valerii Petrovich is a member of the editorial staff, and an author and critic of our journal.

Dear Valerii Petrovich!

The editorial office, editorial staff, and RSSMGFE congratulate you on your jubilee, and wish you good health, and many years of active scientific, creative, and social activity!

Translated from Osnovaniya, Fundamenty i Mekhanika Gruntov, No. 3, p. 32, May-June, 2009. 